\title{
Two-staged revision with custom made prosthesis in septic failure of massive allograft reconstruction after type II-III pelvic resection
}

\author{
Tip II-III pelvik rezeksiyon sonrası masif allogreft rekonstrüksiyonunun septik yetmezliğinde \\ özel yapım protez ile iki basamaklı revizyonu
}

\author{
Şenol Bekmez, M.D., ${ }^{1}$ Mehmet Ayvaz, M.D., ${ }^{2}$ M. Uğur Mermerkaya, M.D., ${ }^{3}$ A. Mazhar Tokgozoglu, M.D. ${ }^{2}$ \\ 'Department of Orthopedics and Traumatology, Dr. Sami Ulus Training and Research Hospital Ankara, Turkey \\ ${ }^{2}$ Department of Orthopedics and Traumatology, Medical Faculty of Hacettepe University, Ankara, Turkey \\ ${ }^{3}$ Department of Orthopedics and Traumatology, Medical Faculty of Bozok University, Yozgat, Turkey
}

\begin{abstract}
Reconstruction of defects occurring during periacetabular resections of pelvic tumors is required particularly in young and functionally active persons. Allograft reconstruction provides good functional outcomes in restoration of normal pelvic anatomy. A 24-year-old male patient was reconstructed with an allograft-prosthesis composite after periacetabular resection due to pelvic chondrosarcoma. After four years, a two-staged revision with a custom-made pelvic prosthesis was performed due to septic failure. Successful radiographic and functional outcomes were achieved at two-year follow-up. In conclusion, we suggest a two-staged revision with a custommade pelvic prosthesis as a satisfactory option in case of septic failure of allograft reconstruction after periacetabular resection.
\end{abstract}

Keywords: Arthroplasty; hip; infection; pelvic neoplasms; reoperation; replacement.

Reconstruction of defects caused by periacetabular tumor resections is a controversial issue in orthopedic oncology. Structural massive allograft reconstruction in young and high-demand patients has been reported to have good functional outcomes. ${ }^{[1]}$ However, high infection rates were associated with allograft reconstruction. ${ }^{[1,2]}$ In this article, we report a case of massive allograft reconstruction after type II-III pelvic resection which eventually failed due to an infection, and was treated with a two-staged revision with a custom-made pelvic prosthesis.
Özellikle genç ve fonksiyonel açıdan aktif kişilerde pelvik tümörlerin periasetabüler rezeksiyonları sırasında meydana gelen defektlerin rekonstrüksiyonu gereklidir. Allogreft rekonstrüksiyonu normal pelvik anatominin restorasyonunda iyi fonksiyonel sonuçlar sağlar. Yirmi dört yaşında erkek hasta pelvik kondrosarkom nedeniyle periasetabüler rezeksiyon sonrası allogreft-protez kompoziti ile rekonstrükte edildi. Dört yıl sonra, septik yetmezlik nedeniyle özel yapım pelvis protezi ile iki basamaklı revizyon uygulandı. İki yıllık takip sonunda başarılı radyografik ve fonksiyonel sonuçlar elde edildi. Sonuç olarak, periasetabüler rezeksiyon sonrası allogreft ile yapılan rekonstrüksiyonun septik başarısızlığı durumunda, özel yapım pelvik protez ile iki aşamalı revizyonu tatmin edici bir seçenek olarak öneriyoruz.

Anahtar sözcükler: Artroplasti; kalça; enfeksiyon; pelvik tümörler; tekrar ameliyat; replasman.

\section{CASE REPORT}

A 24-year-old male patient with complaints of pain and a mass in his left iliac bone was diagnosed as chondrosarcoma when he was 17 years old. Tumor excision was performed twice. Afterwards, he was referred to our institution due to tumor recurrence in the $11^{\text {th }}$ month. After evaluation, a type II-III extra-articular pelvic resection was performed (Figure 1). The defect was reconstructed with a fresh-frozen massive structural pelvic allograft combined with a cemented total hip prosthesis.

- Received: August 29, 2013 Accepted: January 20, 2014

- Correspondence: Şenol Bekmez, M.D. Dr. Sami Ulus Eğitim ve Araştırma Hastanesi Ortopedi ve Travmatoloji Kliniği, 06080 Altındağ, Ankara, Turkey. Tel: +90 312 - 3056254 Fax: +90 312 - 3100161 e-mail: drsenolbekmez@gmail.com 


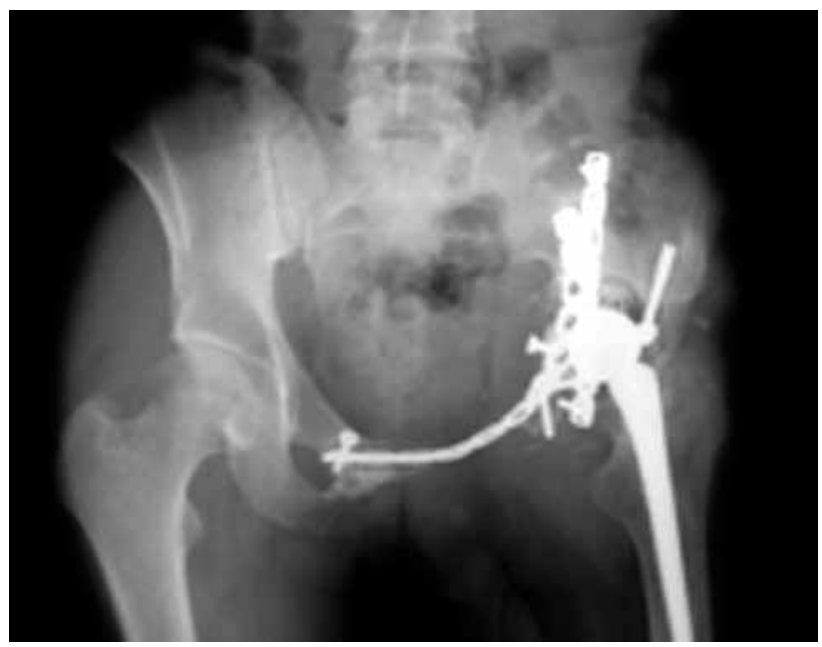

Figure 1. Postoperative X-ray after type II-III resection and reconstruction with a pelvic allograft.

The achievement of allograft-bone union was seen at one-year follow-up. After four years without any complaint and with good functionality, a purulent drainage started from the incision. Erythrocyte sedimentation rate and $C$ reactive protein levels were also elevated. Allograft resorption was detected upon radiographic examination. Following the initial debridement and implant removal, an antibiotic-loaded poly methyl methacrylate spacer was implanted (Figure 2). Femoral component was retained because the infection was limited around allograft and acetabular component, and also there was no radiographic or intraoperative evidence for femoral component loosening. Klebsiella pneumoniae that is sensitive to cefazolin and gentamicin was isolated in deep cultures. Multiple debridements, spacer exchange and supplementary negative pressure wound therapy were utilized for eradication

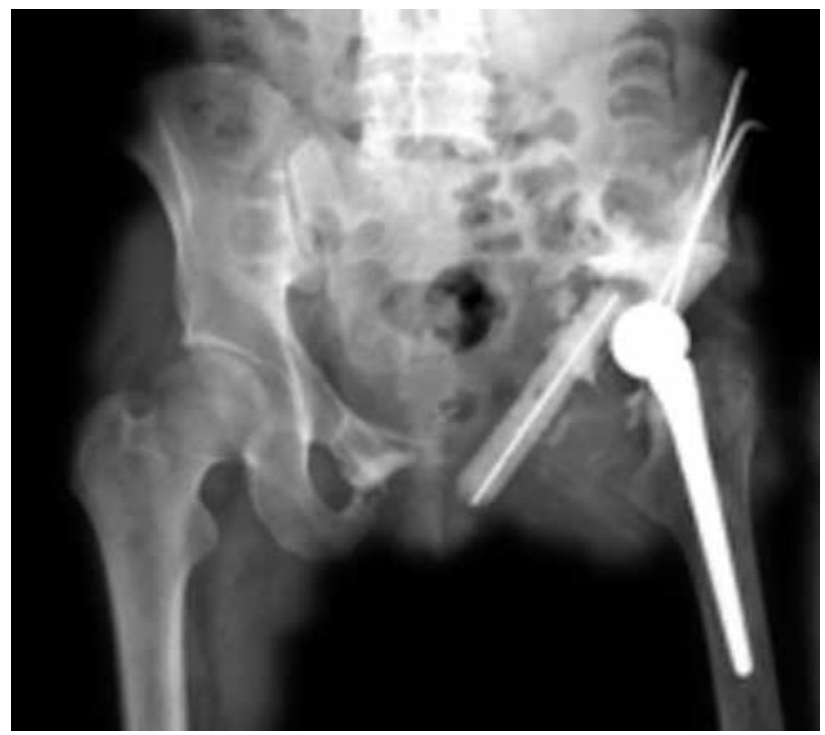

Figure 2. Subsequent to implant removal and serial debridements, antibiotic-impregnated poly methyl methacrylate spacers were implanted due to deep infection at four-year follow-up.

of infection. Appropriate parenteral antibiotics including ciprofloxacin and piperacillin/tazobactam were administered for 12 weeks. Purulent drainage eventually ceased and the wound was healed.

The infection was considered as treated after serological markers improved. Meanwhile, we decided that a reconstruction could be performed thanks to the patient's improved condition. Patient's computed tomography scan was delivered to an implant manufacturer (Waldemar LINK GmbH \& Co. Hamburg, Germany). A custom implant replicating the acetabulum and hemipelvis was manufactured from cobalt-chromium after our approval

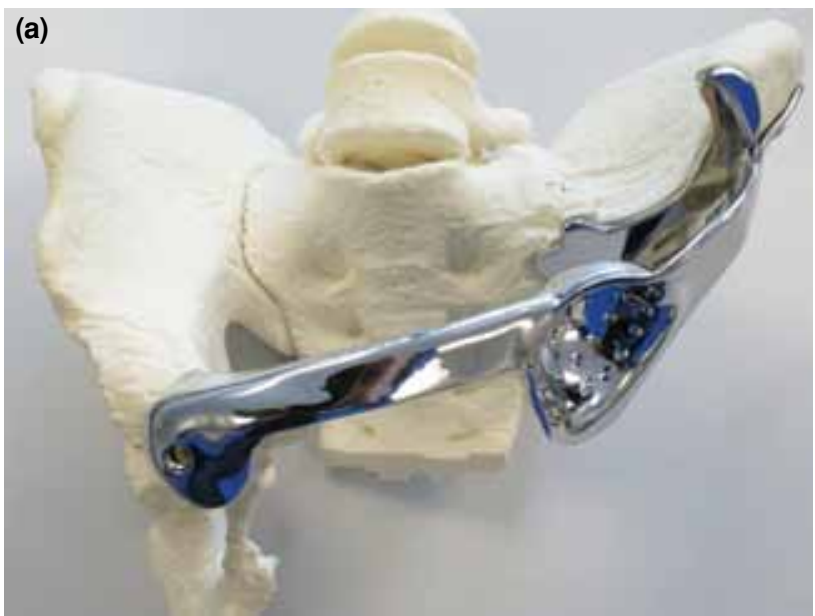

(b)

Figure 3. (a) Anterior and (b) posterior photographs of the custom-made prosthesis. 


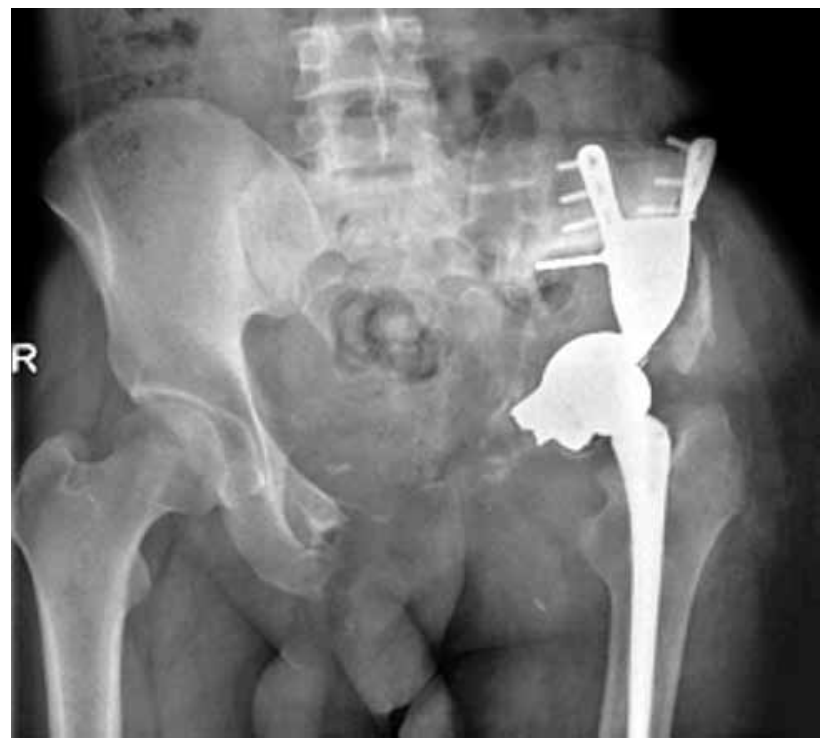

Figure 4. Two-year follow-up after the implantation of the custom-made prosthesis. There is no radiographic sign of implant loosening. The patient has good functional score with negative results for serologic markers.

(Figure $3 a$ and $b$ ). The final implant allowed rigid screw fixation of the implant to the remaining pelvis. Hydroxyapatite coating was applied to the areas where bone contact was planned.

After one to three weeks following the cessation of antibiotics, serological markers were normal indicating that the infection was eradicated. Following removal of the spacer, the custom implant was implanted. We were unable to implant the custom-made prosthesis since the pubic region was not dissectible due to tissue adhesions and scarring. Because of this, the prosthesis was implanted and fixed to the iliac bone with screws after cutting the pubic part of the prosthesis with a metal cutter burr. A polyethylene acetabular constrained insert was cemented into the device and femoral head component was exchanged. The soft tissue defect over the implant was covered with a pedicled rectus abdominis flap.

At two years follow-up, the patient remains to be infection free based on inflammatory markers. The patient is pain free and able to walk without additional support. The Musculoskeletal Tumor Society score is satisfactory (20-Good) (Figure 4).

\section{DISCUSSION}

Resection of malignant tumors in the periacetabular region without reconstruction leads to limb length inequality and mechanical instability; therefore, results in poor functional outcomes. Because of this, reconstruction of the defect is imperative particularly in young and high-demand patients. The main advantages of massive allograft reconstruction are restoration of the pelvic bony architecture, a durable fixation with bony union providing normal biology, and good function in concomitance with a total hip prosthesis. $^{[1-4]}$ However, high complication rates are associated with allograft reconstruction after pelvic resections. ${ }^{[4-6]}$ Infection is one of the most frequent and disastrous complications. Late-onset infection occurred in our patient at four-year follow-up.

Resection of all allograft-prosthesis composite followed by infection eradication brought us to the starting point with a mechanically instable hip joint and a shortened limb in a young and active patient. Leaving the patient with a flail hip would leave the patient with poor functional outcome. Revision with a fresh frozen allograft was not reasonable due to poor vascularity and low healing potential at the surgical site because of multiple debridements.

Custom made pelvic prosthesis is a commonly used option for reconstruction after periacetabular resection. ${ }^{[7,8]}$ With this in mind, we choose to treat our patient with a two-staged revision using a custommade prosthesis. This option enabled us to restore the hip joint anatomy and center of rotation with meticulous planning. Nevertheless, there are major concerns regarding custom-made pelvis prostheses. Despite preoperative planning, there still may be a mismatch on patient during implantation. ${ }^{[9]}$ Fortunately, we did not experience such a problem. Also, pelvic prostheses are associated with primary stability problems, high rates of loosening in longterm and high dislocation rates (3.5 to $20 \%$ ). ${ }^{[7,9,10]}$ Until now, we did not observe these problems. To decrease the potential for aseptic loosening, we had the implant coated with hydroxyapatite where bone contact was expected. Options were provided for rigid fixation to the bone. The problem of dislocation was solved with a constrained acetabular insert. Five-year survival of similar implants was reported as 42 to $76 \%$ in the literature. ${ }^{[7,9,10]}$ In two-year follow-up, our patient is symptom free. He is able to walk without any external support and has a good functional outcome. Also, radiographic evaluation shows no sign of implant loosening.

\section{Conclusion}

Septic failure of a pelvic reconstruction made with an allograft-prosthesis composite can be salvaged with a two-staged revision using an antibiotic impregnated cement spacer and custom-made pelvis prosthesis. 


\section{Declaration of conflicting interests}

The authors declared no conflicts of interest with respect to the authorship and/or publication of this article.

\section{Funding}

The authors received no financial support for the research and/or authorship of this article.

\section{REFERENCES}

1. Delloye C1, Banse X, Brichard B, Docquier PL, Cornu O. Pelvic reconstruction with a structural pelvic allograft after resection of a malignant bone tumor. J Bone Joint Surg [Am] 2007;89:579-87.

2. Campanacci D, Chacon S, Mondanelli N, Beltrami G, Scoccianti G, Caff G, et al. Pelvic massive allograft reconstruction after bone tumour resection. Int Orthop 2012;36:2529-36.

3. Langlais F, Lambotte JC, Thomazeau H. Long-term results of hemipelvis reconstruction with allografts. Clin Orthop Relat Res 2001;178-86.

4. Donati D, Di Bella C, Frisoni T, Cevolani L, DeGroot H.
Alloprosthetic composite is a suitable reconstruction after periacetabular tumor resection. Clin Orthop Relat Res 2011;469:1450-8.

5. Flóris I, Bodzay T, Vendégh Z, Gloviczki B, Balázs P. Shortterm results of total hip replacement due to acetabular fractures. Eklem Hastalik Cerrahisi 2013;24:64-71.

6. Ozaki T, Hillmann A, Bettin D, Wuisman P, Winkelmann W. High complication rates with pelvic allografts. Experience of 22 sarcoma resections. Acta Orthop Scand 1996;67:333-8.

7. Rudert M, Holzapfel BM, Pilge H, Rechl H, Gradinger R. Partial pelvic resection (internal hemipelvectomy) and endoprosthetic replacement in periacetabular tumors. Oper Orthop Traumatol 2012;24:196-214. [Abstract]

8. Guo W, Li D, Tang X, Yang Y, Ji T. Reconstruction with modular hemipelvic prostheses for periacetabular tumor. Clin Orthop Relat Res 2007;461:180-8.

9. Jaiswal PK, Aston WJ, Grimer RJ, Abudu A, Carter S, Blunn $G$, et al. Peri-acetabular resection and endoprosthetic reconstruction for tumours of the acetabulum. J Bone Joint Surg [Br] 2008;90:1222-7.

10. Ozaki T, Hoffmann C, Hillmann A, Gosheger G, Lindner N, Winkelmann W. Implantation of hemipelvic prosthesis after resection of sarcoma. Clin Orthop Relat Res 2002;197-205. 